\title{
Identifikasi Alkohol dalam Hand Sanitizer secara Fourier Transform Infra Red (FTIR) dan Kemometrik
}

\author{
Kusuma Hendrajaya, Nur Jamaliah, dan Azminah
}

Fakultas Farmasi, Universitas Surabaya, Surabaya, Indonesia

Korespondensi: Azminah

Email:azminah@staff.ubaya.ac.id

Submitted: 16-08-2021, Revised: 16-11-2021, Accepted: 20-12-2021

\begin{abstract}
ABSTRAK: Hand sanitizer merupakan produk yang mengandung zat antiseptik untuk mencuci tangan tanpa harus dibilas dengan air. Alkohol sebagai bahan aktif dalam hand sanitizer banyak digunakan sebagai antiseptik yang mempunyai aktivitas bakterisidal. Saat pandemi covid-19 banyak hand sanitizer yang beredar di pasaran dengan kadar alkohol antara 60\%-80\%. Identifikasi adanya alkohol umumnya dengan metode kromatografi gas. Metode analisis untuk identifikasi alkohol dalam hand sanitizer dengan menggunakan spektrometer Fourier Transform Infra Red (FTIR) dan kemometrik dapat digunakan dengan penyiapan sampel yang lebih sederhana dan cepat. Spektrum FTIR menampilkan puncak-puncak dari gugus fungsi dan ikatan kimia dari senyawa-senyawa dalam sampel. Data spektrum FTIR dikombinasikan dengan metode kemometrik (PCA, analisis kluster, dan PLS), digunakan untuk identifikasi dan mengelompokkan sampel uji hand sanitizer dan standar hand sanitizer. Hasil menunjukkan metode spektrometri FTIR dan kemometrik dapat mengidentifikasi dan mengelompokkan sampel uji hand sanitizer dan standar hand sanitizer dengan variasi kadar alkohol dalam hand sanitizer $60 \%, 65 \%, 70 \%, 75 \%$, dan $80 \%$.
\end{abstract}

Kata kunci: alkohol; hand sanitizer; kemometrik; spektrometer FTIR

\begin{abstract}
Hand sanitizer is a product that contains antiseptic substances to wash hands without having to rinse with water. Alcohol as an active ingredient in hand sanitizer is widely used as an antiseptic which has bactericidal activity. During the COVID-19 pandemic, there are many hand sanitizers on the market containing alcohol between $60 \%$ and $80 \%$. Identification of the presence of alcohol is generally conducted by gas chromatography method. The analytical method for identification of alcohol in hand sanitizer using Fourier Transform Infra Red (FTIR) spectrometer and chemometrics can be used with simpler and faster sample preparation. The FTIR spectrometer displays the peaks of the functional groups and chemical bonds of the compounds in the samples. FTIR spectra combined with chemometric methods (PCA, cluster analysis, and PLS) were used to identify and classify hand sanitizer test samples and standards. The results show that FTIR and chemometric methods can identify and classify hand sanitizer test samples and standards with variations in alcohol content (60\%, 65\%, 70\%, 75\% and 80\%).
\end{abstract}

Keywords: alcohol; chemometrics; FTIR spectrometer; hand sanitizer 


\section{Pendahuluan}

Hand sanitizer merupakan produk pembersih tangan yang mengandung zat antiseptik yang digunakan untuk mencuci tangan tanpa harus membilasnya dengan air [1]. Penggunaan hand sanitizer sangat mudah diaplikasikan dengan meneteskan pada telapak tangan kemudian meratakan ke permukaan telapak tangan. Hand sanitizer berbahan aktif alkohol sangat baik untuk membersihkan tangan hanya ketika tangan dalam keadaan bersih untuk memastikan kuman benarbenar mati [2]. Menurut World Health Organization (WHO) dan Centers for Disease Control and Prevention (CDC) kandungan alkohol dalam hand sanitizer yang berfungsi sebagai antiseptik pada rentang 60-95\% [2,3,4]. Meskipun dapat membunuh mikroorganisme dan virus, kadar alkohol diatas $80 \%$ juga tidak disarankan karena cepat menguap. Banyak penelitian yang telah dilakukan terkait efektifias kandungan alkohol dalam hand sanitizer, dimana hasilnya menunjukkan bahwa kandungan alkohol 60-80\% memberikan efikasi yang baik sebagai antiseptik [5,6]. Produk hand sanitizer yang beredar di Indonesia mempunyai kandungan alkohol pada rentang $60-80 \%$.

Untuk mengidentifikasi dan menentukan kandungan alkohol dalam suatu produk umumnya digunakan metode analisis kromatografi gas $[7,8,9,10]$. Penyiapan sampel pada analisis dengan gas kromatografi tidak sederhana dan relatif mahal. Oleh karena itu, metode analisis alkohol dengan penyiapan sampel yang cepat dan sederhana perlu dikembangkan. Metode analisis dengan spektroskopi FTIR dan kemometrik sat ini banyak dikembangkan untuk identifikasi dan pengelompokan, serta analisis kuantitatif.

Spektroskopi FTIR menghasilkan spektrum yang merupakan hasil interaksi antara senyawasenyawa kimia dalam sampel yang rumit. Spektrum FTIR kaya akan informasi struktur molekular dengan banyak puncak serapan yang spesifik untuk gugus fungsi dan ikatan kimia [11]. Spektroskopi FTIR memiliki kelebihan dalam penyiapan sampel yang cepat dan sederhana, serta langsung dapat dianalisis tanpa proses pemisahan
$[12,13]$. Namun demikian spektroskopi FTIR juga memiliki kekurangan, yaitu analit dalam sampel tidak dipisahkan sehingga dapat terjadi tumpang tindih spektrum serapan dari senyawa-senyawa dalam sampel tersebut. Oleh karena itu dapat dibantu dengan kemometrik untuk mengolah data spektrumnya $[14,15,16]$.

Penelitian ini bertujuan mengembangkan metode analisis untuk mengidentifikasi alkohol dalam gel hand sanitizer dengan spektroskopi FTIR dan kemometrik. Metode kemometrik yang digunakan adalah Principle Component Analysis (PCA), Cluster Analysis (CA) untuk mengelompokkan, dan Partial Least Square (PLS) untuk melihat hubungan kuantitatif antara data multivariant dari spektrum FTIR dengan kadar alkohol dalam sampel.

\section{Metode penelitian}

\subsection{Alat dan bahan}

Alat-alat yang digunakan adalah spektrometer Fourier Transform Infra Red (FTIR, Agilent Cary 630), perangkat PC (Personal Computer), mikropipet (Socorex 0,5-5,0 ml), neraca analitik (OHAUS), mortir dan stamper, serta alat-alat gelas laboratorium. Bahan-bahan yang digunakan meliputi alkohol 96\% (Merck), karbomer 940, metilparaben, gliserin, trietanolamin, dan aquadestilata.

\subsection{Pembuatan hand sanitizer}

Dibuat standar hand sanitizer yang mengandung alkohol 60, 65, 70, 75, 80\%. Formula hand sanitizer dalam skala $25 \mathrm{ml}$ terdiri dari bahan aktif alkohol (masing masing 60, 65, 70, 75, 80\%), dengan karbomer 940 (0,5 g) sebagai basis gel, gliserin $(0,5 \mathrm{ml})$ sebagai emolien, metilparaben $(0,5 \mathrm{~g})$ sebagai pengawet, dan trietanolamin $(0,6$ $\mathrm{ml}$ ) sebagai alkalizing agent, serta aquadestilata [17].

\subsection{Analisis data}

Standar alkohol 60\%,65\%, 70\%, 75\%, 80\%, dan 5 sampel uji (EL, DT, ES, SN, IT) masing- 
masing dibaca data absorbansi dengan spektrometer FTIR pada bilangan gelombang 4000-400 $\mathrm{cm}^{-1}$. Data selanjutnya diolah secara kemometrik dengan Principle Component Analysis (PCA), Cluster Analysis (CA), dan Partial Least Square (PLS). Analisis dilakukan dengan bantuan perangkat lunak Minitab ${ }^{\circledR} 18.1$.

\section{Hasil dan pembahasan}

Spektrum FTIR dari standar alkohol, standar hand sanitizer, dan sampel uji EL, DT, ES, SN, dan IT memiliki pola yang mirip dan tidak menunjukkan adanya perbedaan yang khas (Gambar 1). Struktur alkohol terdiri dari gugus metil, metilen, dan hidroksi (Gambar 2). Perbedaan terletak pada intensitas serapannya. Puncak-puncak yang teramati pada spektrum tersebut adalah pada bilangan gelombang $800-750 \mathrm{~cm}^{-1}$ terdapat vibrasi tekuk C-H, pada $1085-1050 \mathrm{~cm}^{-1}$ terdapat vibrasi ulur C-O, bilangan gelombang 2000-1600 $\mathrm{cm}^{-1}$ menunjukkan adanya vibrasi tekuk $\mathrm{C}-\mathrm{H}$, pada 3000-2840 $\mathrm{cm}^{-1}$ adanya vibrasi ulur C-H dari metil, dan pada $3400-3200 \mathrm{~cm}^{-1}$ ada vibrasi ulur O-H [18]. Hal ini menunjukkan adanya gugus hidroksi dari alkohol atau metil paraben dan trietanolamin, dan ikatan C-H (metil) dari alkohol atau metil paraben.

Untuk dapat membedakan dan mengelompokkan data spektrum FTIR tersebut, maka data diolah dengan kemometrik. Data spektrum dari standar alkohol, standar hand sanitizer, dan sampel uji diolah dengan metode Principle Com-

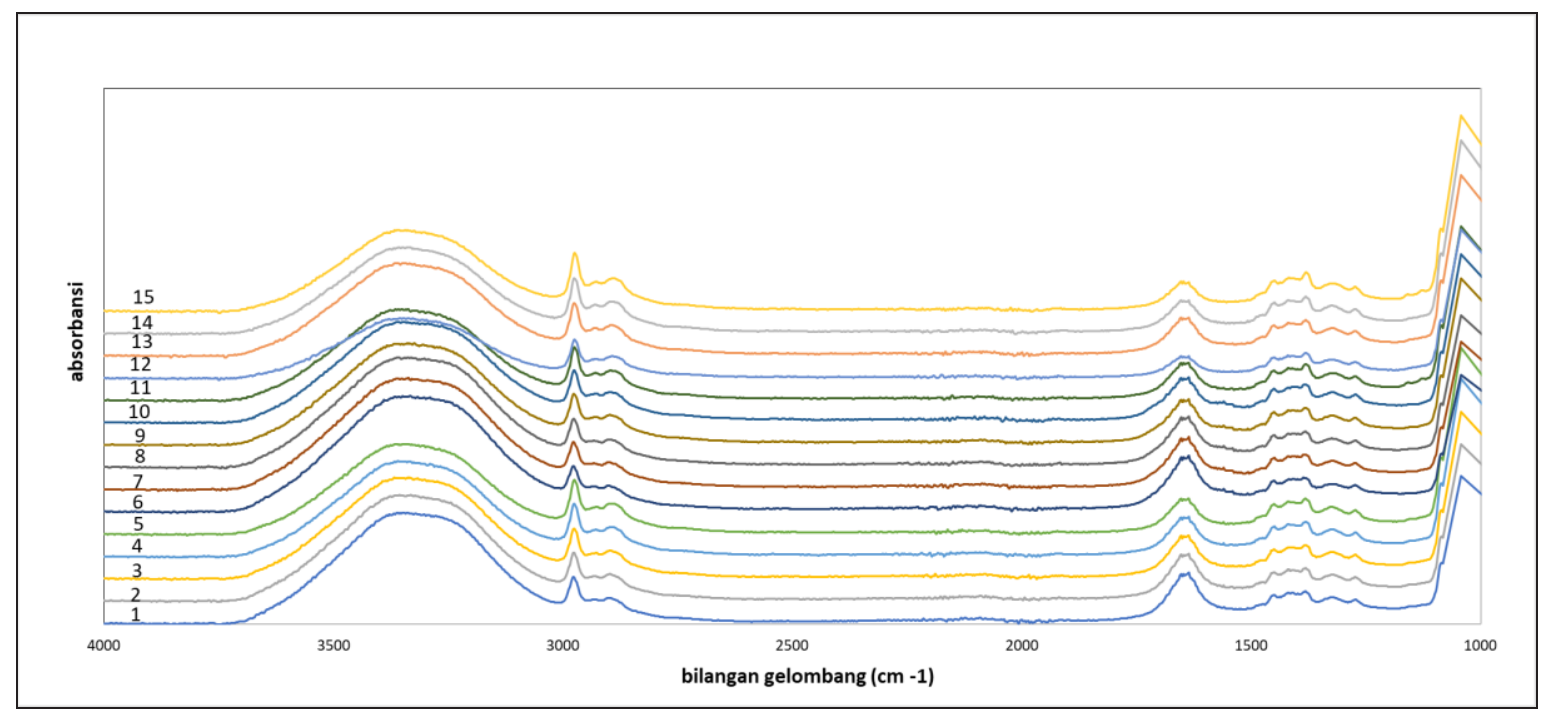

Gambar 1. Spektra ATR-FTIR. 1-5 berturut-turut menyatakan standar alkohol 60\%, 65\%, 70\%, 75\%, dan 80\%; 6-10 berturut-turut menunjukkan hand sanitizer alkohol 60\%,65\%, 70\%, 75\%, dan 80\%; 11-15 berturut-turut menyatakan sampel hansanitizer merk EL, DT, SS, SN, dan IT

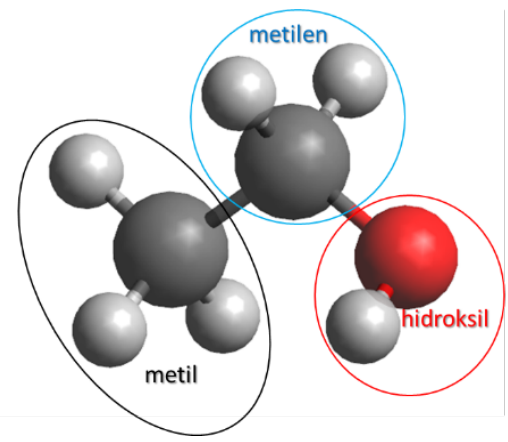

Gambar 2. Struktur 3 dimensi (3D) etanol yang terdiri dari gugus metil, metilen, hidroksi 
ponent Analysis (PCA) dan Cluster Analisis (CA). PCA adalah suatu Teknik dalam kemometrik untuk pengelompokkan. Teknik ini mereduksi data multivarian, ketika antar variabel terjadi korelasi. Ketika suatu sampel mempunyai Principle Component (PC) yang hampir sama, maka akan mempunyai sifat kimia fisika yg hampir sama juga sehingga dapat dikelompokkan. Untuk kalibrasi multivarian dari data spektrum FTIR digunakan Partial Least Square (PLS) yang bertujuan untuk melihat hubungan linear dari banyak variabel dalam spektrum FTIR terhadap konsentrasi analit $[19,20]$.

Data spektrum yang diolah dengan PCA menggunakan program Minitab berasal dari 14 bilangan gelombang, yaitu $3337 \mathrm{~cm}^{-1}, 2972 \mathrm{~cm}^{-1}, 2933$ $\mathrm{cm}^{-1}, 2877 \mathrm{~cm}^{-1}, 1638 \mathrm{~cm}^{-1}, 1576 \mathrm{~cm}^{-1}, 1448 \mathrm{~cm}^{-1}$, $1412 \mathrm{~cm}^{-1}, 1377 \mathrm{~cm}^{-1}, 1325 \mathrm{~cm}^{-1}, 1267 \mathrm{~cm}^{-1}, 1082$ $\mathrm{cm}^{-1}, 1043 \mathrm{~cm}^{-1}$, dan $875 \mathrm{~cm}^{-1}$ yang merupakan puncak-puncak utama dari spektrum FTIR. Hasil pengelompokan dengan metode PCA dapat dilihat pada Gambar 3. Gambar tersebut menunjukkan hubungan 14 komponen utama (PC) dengan eigenvalue. PC1 mempunyai varians 8,5567 atau $61,1 \%$ dari varians total, PC2 mempunyai varians 5,1226 atau $97,7 \%$ dari varians total. PC3 mempunyai varians 0,2628 atau $99,6 \%$ dari varians total. PC4 dan PC5 mempunyai varians 99,9\% dari varians total. PC6 sampai PC14 mempunyai varians $100 \%$ dari varians total. Hasil ini menunjukkan metode PCA dapat mengurangi data variabel yang awal ada 14 variabel (bilangan gelombang) dapat dijelaskan menjadi 5 variabel baru (sampai PC5), karena sampai PC5 sudah mampu mengekstrak informasi sebesar 99,9\%.

Hubungan nilai PC1 dan PC2 dapat dilihat dari Gambar 4. Gambar tersebut menunjukkan score plot komponen utama (PC1 dan PC2) yang terdiri dari standar alkohol 60\% (1), standar alkohol $65 \%$ (2), standar alkohol 70\% (3), standar alkohol 75\% (4), standar alkohol 80\% (5), hand sanitizer alkohol 60\% (6), hand sanitizer alkohol 65\% (7), hand sanitizer alkohol 70\% (8), hand sanitizer alkohol 75\% (9), hand sanitizer alkohol 80\% (10), sampel hand sanitizer merk EL (11), sampel hand sanitizer merk DT (12), sampel hand sanitizer merk SS (13), sampel hand sanitizer merk SN (14), serta sampel hand sanitizer merk IT (15).

Hasil analisis hubungan score plot PC1 dan PC2 sampel 1 (standar alkohol 60\%), 2 (standar alkohol 65\%), 6 (hand sanitizer alkohol 60\%), 7 (hand sanitizer alkohol 65\%), dan 8 (hand sanitizer alkohol 70\%) menunjukkan jarak yang berdekatan. Score plot dari PC1 dan PC2 sampel 3 (standar alkohol 70\%), 9 (hand sanitizer alkohol 75\%), dan 10 (hand sanitizer alkohol 80\%) menunjukkan jarak yang berdekatan. Score plot dari PC1 dan PC2 sampel 4 (standar alkohol 75\%)

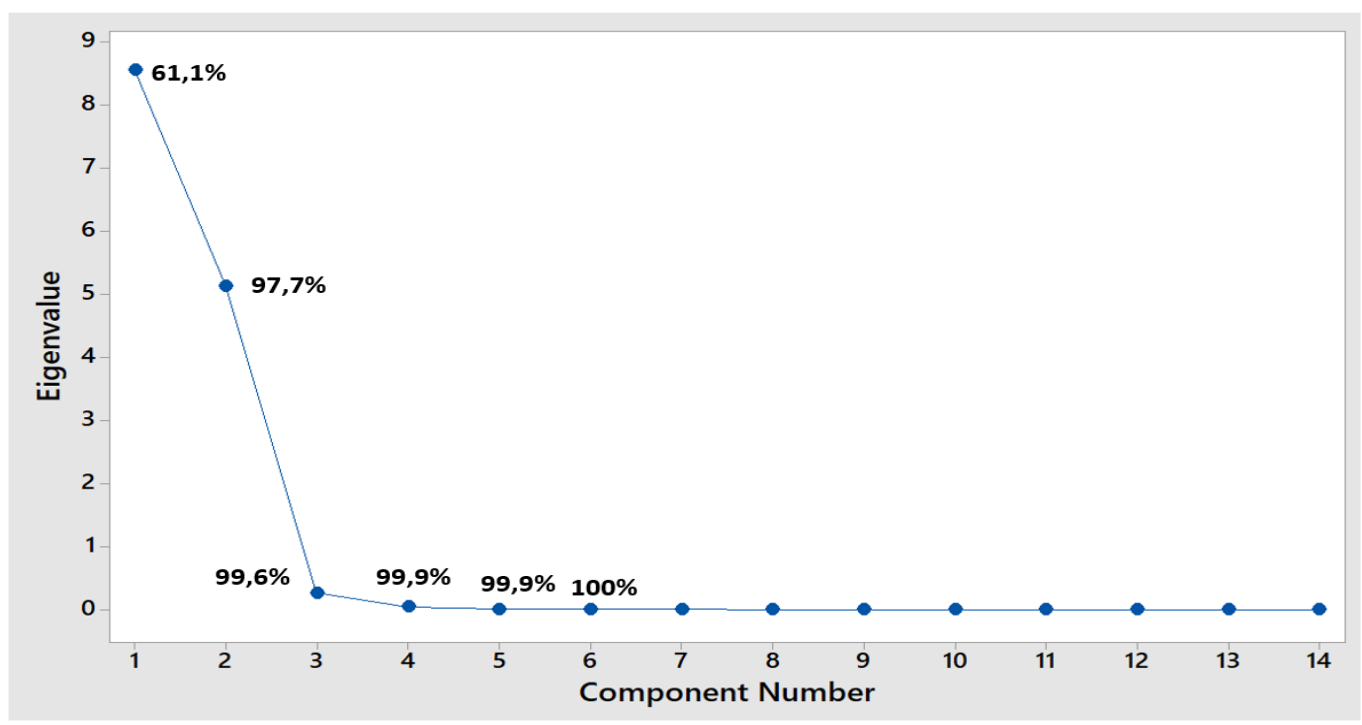

Gambar 3. Hubungan antara PC (1-14 komponen utama) dan eigenvalue 


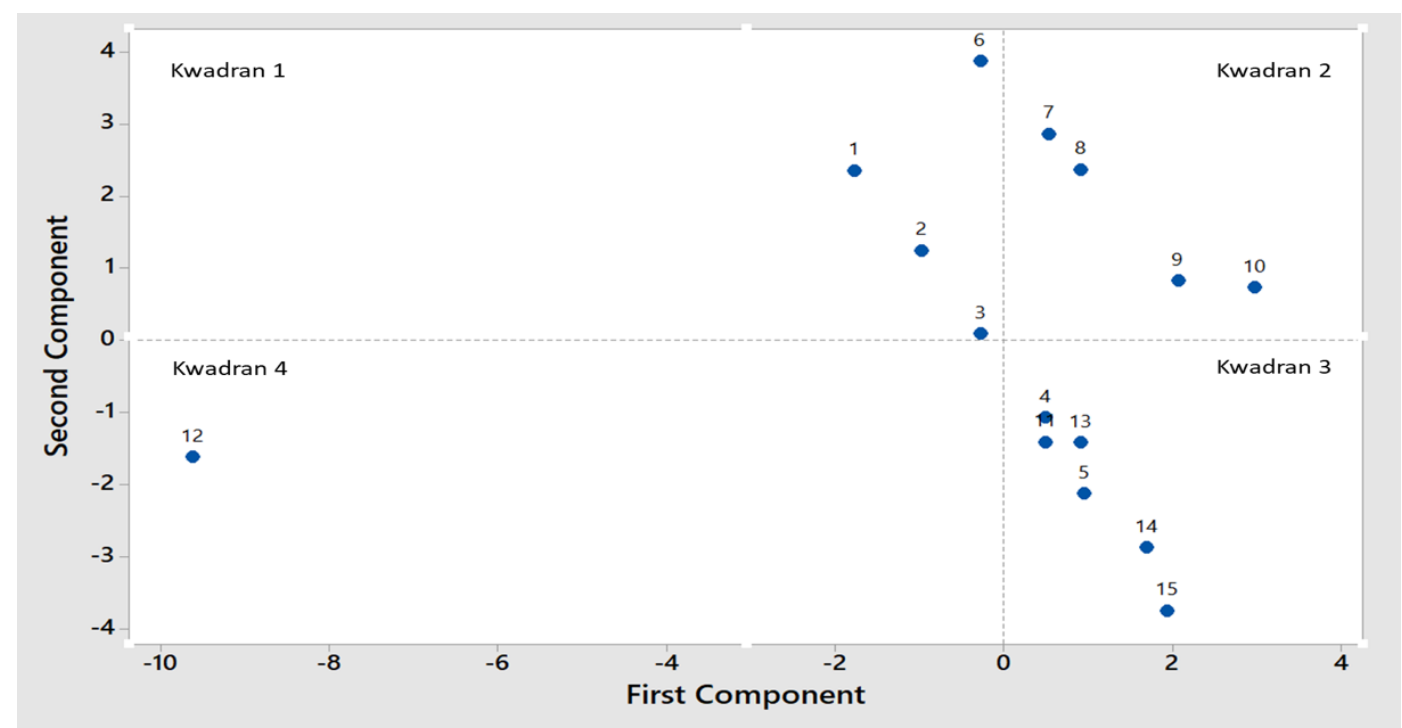

Gambar 4. Korelasi skor plot dari PC1 dan PC2 dari standar/sampel 1-15. 1-5 berturut-turut menyatakan standar alkohol 60\%,65\%, 70\%, 75\%, dan 80\%; 6-10 berturut-turut menunjukkan hand sanitizer alkohol 60\%, 65\%, 70\%, 75\%, dan 80\%; 11-15 berturut-turut menyatakan sampel hansanitizer merk EL, DT, SS, SN, dan IT

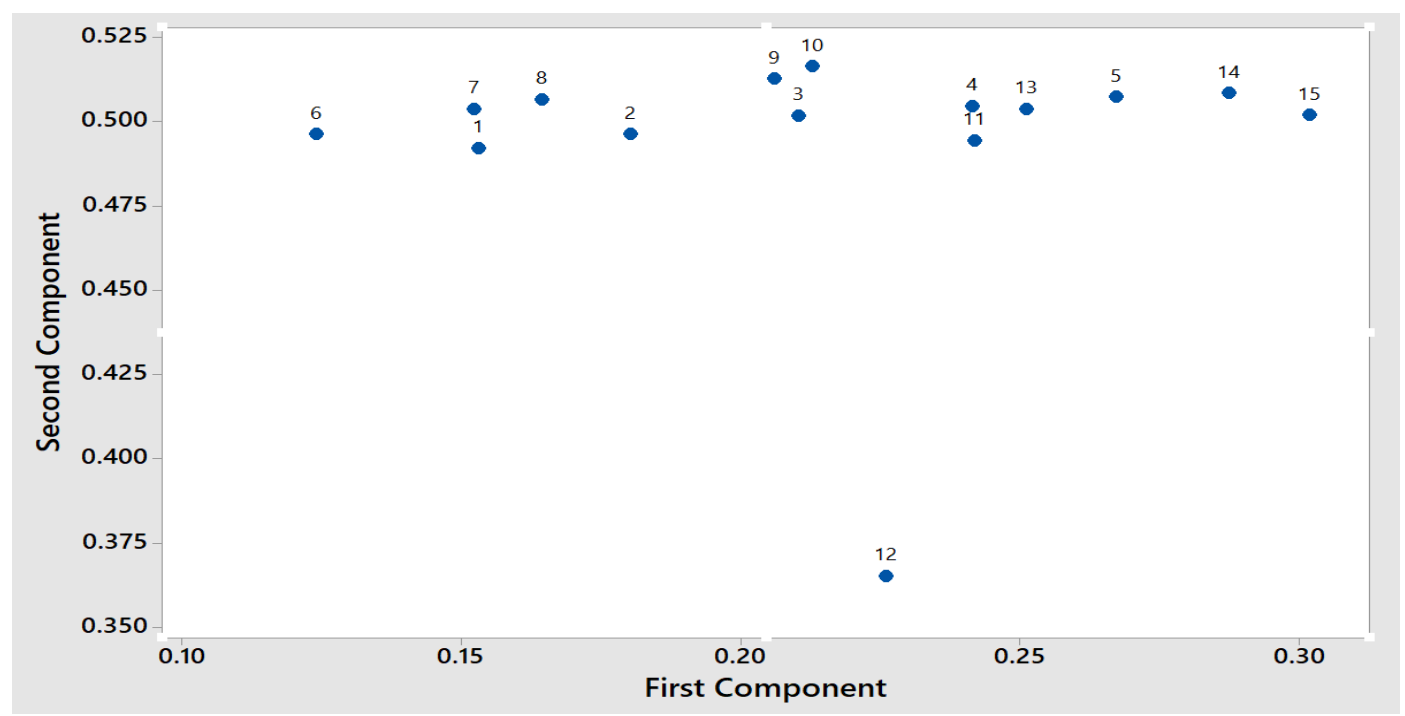

Gambar 5. Kovarians skor plot dari PC1 dan PC2 dari standar 1-15. 1-5 berturut-turut menyatakan standar alkohol 60\%, 65\%, 70\%, 75\%, dan 80\%; 6-10 berturut-turut menunjukkan hand sanitizer alkohol 60\%, 65\%, 70\%, 75\%, dan 80\%; 11-15 berturut-turut menyatakan sampel hansanitizer merk EL, DT, SS, SN, dan IT

menunjukkan kedekatan dengan 11 (sampel merk EL) dan 13 (sampel merk SS). Hasil analisis menggunakan metode pengelompokkan dengan PCA mampu mengelompokkan serangkaian data dengan menunjukkan jarak kedekatan score plot PC1 dan PC2 dari sampel.

Gambar 5 menunjukkan visualisasi 2D (2 dimensi) PCA dalam bentuk kwadran (matriks korelasi) PC1 dan PC2 dari 14 bilangan gelombang.
Kuadran 1 terdiri dari: standar alkohol 60\% (1), standar alkohol 65\% (2), standar alkohol 70\% (3), dan standar hand sanitizer alkohol 60\% (6). Pada kuadran 2 terdiri dari: standar hand sanitizer alkohol 65\% (7), standar hand sanitizer alkohol 70\% (8), standar hand sanitizer alkohol 75\% (9), dan standar hand sanitizer alkohol 80\% (10). Pada kwadran 3 terdiri dari standar alkohol 75\% (4), standar alkohol 80\% (5), sampel uji hand sa- 


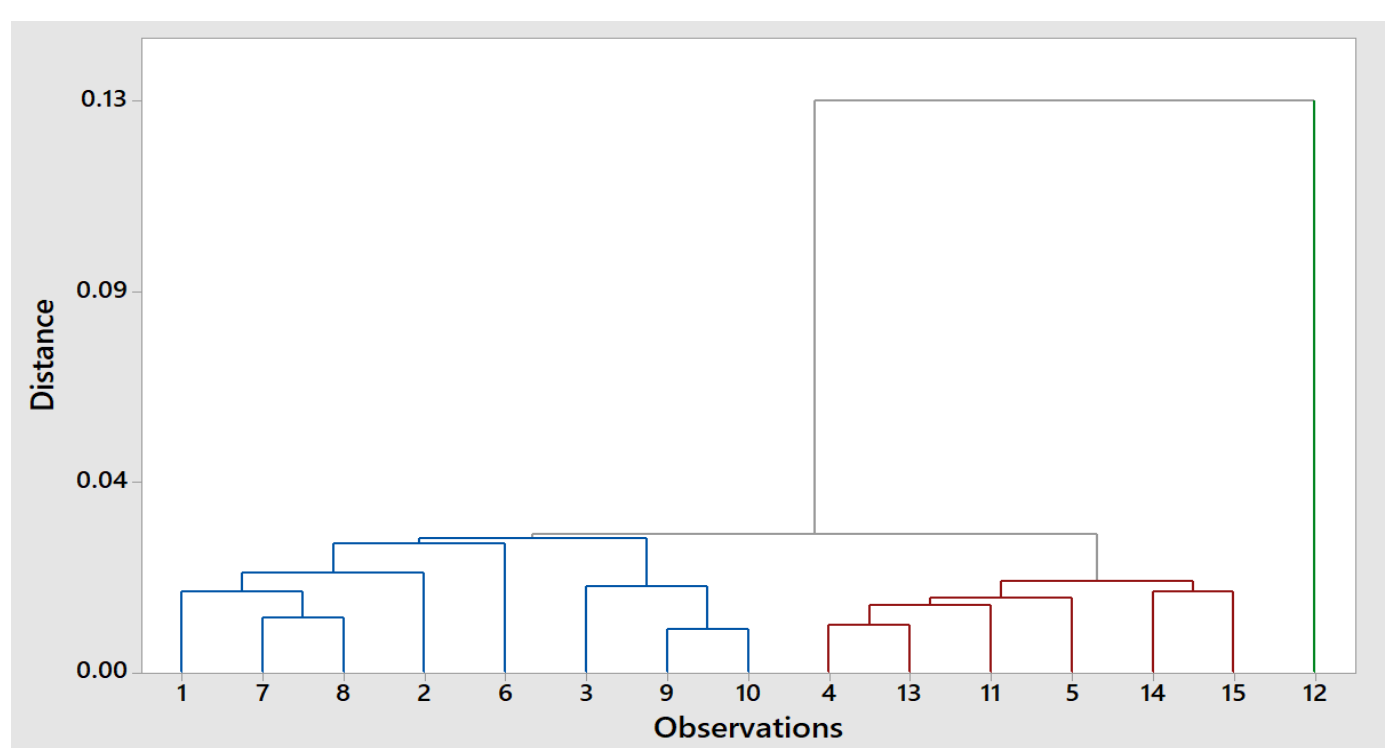

Gambar 6. Dendogram Analisis kluster dari pengelompokan standar alkohol dan sampel uji. 1-5 berturut-turut menyatakan standar alkohol 60\%,65\%, 70\%, 75\%, dan 80\%; 6-10 berturut-turut menunjukkan hand sanitizer alkohol 60\%,65\%, 70\%, 75\%, dan 80\%; 11-15 berturut-turut menyatakan sampel hansanitizer merk EL, DT, SS, SN, dan IT

nitizer EL (11), sampel uji hand sanitizer SS (13), sampel uji hand sanitizer SN (14), dan sampel uji hand sanitizer IT (15). Kwadran 4 terdiri dari sampel uji hand sanitizer DT (12). Dari hasil pengelompokan dengan PCA dapat diprediksi bahwa sampel uji hand sanitizer merk EL, SS, SN, dan IT mengandung alkohol 75\%-80\% karena terletak pada satu kwadran. Pada kuadran 4 hanya ada satu sampel yaitu hand sanitizer merk DT (12).

Pengelompokan bentuk lain yaitu analisis kluster dengan pengolahan data spektrum menggunakan bantuan program Minitab pada 14 bilangan gelombang. Dari analisis kluster diperoleh dendogram seperti yang ditunjukkan pada Gambar 6. Tabel 1 menunjukkan bahwa tahaptahap penghubung dengan skala vertikal memberikan jarak dan kemiripan antara 2 kelompok pada suatu titik ketika kedua kelompok ini digabungkan yaitu nomor 9 (hand sanitizer 75\%) dan nomor 10 (hand sanitizer alkohol 80\%) dengan jarak 0,0098 dan kemiripan 94,48\% sehingga digabungkan dan diberi nama kelompok/kluster baru 1, nomor 4 (standar alkohol 75\%) dan nomor 13 (sampel merk SS) dengan jarak 0,010 dan kemiripan 93,89\% sehingga digabungkan dan diberi nama kelompok/kluster baru 2, nomor 7 (hand sanitizer alkohol 65\%) dan nomor 8 (hand sanitizer alkohol 70\%) dengan jarak 0,0125 dan kemiripan 92,95\% sehingga digabungkan dan diberi nama kelompok/kluster baru 1, nomor 4 (standar alkohol 75\%) dan nomor 11 (sampel merk EL) dengan jarak 0,015 dan kemiripan 91,317\% sehingga digabungkan dan diberi nama kelompok/kluster baru 2, nomor 4 (standar alkohol 75\%) dan nomor 5 (standar alkohol 80\%) dengan jarak 0,0169 dan kemiripan 90,47\% sehingga digabungkan dan diberi nama kelompok/kluster baru 2, nomor 1 (standar alkohol 60\%) dan nomor 7 (hand sanitizer alkohol 65\%) dengan jarak 0,0184 dan kemiripan 89,63\% sehingga digabungkan dan diberi nama kelompok/ kluster baru 1, nomor 14 (merk SN) dan nomor 15 (merk IT dengan jarak 0,0184 dan kemiripan 89,63\% sehingga digabungkan dan diberi nama kelompok/kluster baru 2, nomor 3 (standar alkohol 70\%) dan nomor 9 (hand sanitizer 75\%) dengan jarak 0,019 dan kemiripan 88,989\% sehingga digabungkan dan diberi nama kelompok/ kluster baru 1, nomor 4 (standar alkohol 75\%) dan nomor 14 (merk SN) dengan jarak 0,02 dan kemiripan 88,31\% sehingga digabungkan dan diberi nama kelompok/kluster baru 2, nomor 
Tabel 1. Hasil penggabungan dalam Cluster Analysis dengan perangkat lunak Minitab ${ }^{\circledR} 18.1$

\begin{tabular}{lllllll}
\hline Step & $\begin{array}{l}\text { Number of } \\
\text { clusters }\end{array}$ & $\begin{array}{l}\text { Similarity } \\
\text { level }\end{array}$ & $\begin{array}{l}\text { Distance } \\
\text { level }\end{array}$ & $\begin{array}{l}\text { Clusters } \\
\text { joined }\end{array}$ & $\begin{array}{l}\text { New } \\
\text { cluster }\end{array}$ \\
\hline 1 & 14 & 94.4818 & 0.009818 & 9 & 10 & 1 \\
\hline 2 & 13 & 93.8959 & 0.010861 & 4 & 13 & 1 \\
\hline 3 & 12 & 92.9540 & 0.012536 & 7 & 8 & 1 \\
\hline 4 & 11 & 91.3170 & 0.015449 & 4 & 11 & 2 \\
\hline 5 & 10 & 90.4727 & 0.016951 & 4 & 5 & 2 \\
\hline 6 & 9 & 89.6364 & 0.018439 & 1 & 7 & 1 \\
\hline 7 & 8 & 89.6343 & 0.018443 & 14 & 15 & 1 \\
\hline 8 & 7 & 88.9891 & 0.019591 & 3 & 9 & 1 \\
\hline 9 & 6 & 88.3152 & 0.020790 & 4 & 14 & 1 \\
\hline 10 & 5 & 87.1932 & 0.022786 & 1 & 2 & 1 \\
\hline 11 & 4 & 83.4379 & 0.029468 & 1 & 6 & 3 \\
\hline 12 & 3 & 82.8120 & 0.030581 & 1 & 3 & 2 \\
\hline 13 & 2 & 82.2875 & 0.031514 & 1 & 4 & 2 \\
\hline 14 & 1 & 26.7738 & 0.130285 & 1 & 12 & 2 \\
\hline
\end{tabular}

Tabel 2. Hasil korelasi kadar alkohol dengan metode PLS

\begin{tabular}{lllllll}
\hline Bilangan gelombang $\left(\mathbf{c m}^{-1}\right)$ & $\boldsymbol{R}^{2}$ & Error & PRESS & $\boldsymbol{R}^{2}$ (pred) & RMSEC & RMSEP \\
\hline 4000-1000 (14 puncak) & 0,99783 & 0,0000544 & 0,0001971 & 0,992118 & 0,00329 & 0,006278 \\
\hline $2935-3013$ & 0,99802 & 0,0000494 & 0,0001361 & 0,994557 & 0,00314 & 0,005574 \\
$3017-3060$ & 0,997 & 0,0000749 & 0,0002059 & 0,991762 & 0,00387 & 0,006418 \\
\hline
\end{tabular}

1 (standar alkohol 60\%) dan nomor 2 (standar alkohol 65\%) dengan jarak 0,0227 dan kemiripan $87,19 \%$ sehingga digabungkan dan diberi nama kelompok/kluster baru 1, nomor 1 (standar alkohol 60\%) dan nomor 6 (hand sanitizer 60\%) dengan jarak 0,029 dan kemiripan 83,437\% sehingga digabungkan dan diberi nama kelompok/ kluster baru 1, nomor 1 (standar alkohol 60\%) dan nomor 3 (standar alkohol 70\%) dengan jarak 0,03 dan kemiripan $82,81 \%$ sehingga digabungkan dan diberi nama kelompok/kluster baru 1, nomor 1 (standar alkohol 60\%) dan nomor 4(standar alkohol 75\%) dengan jarak 0,031 dan kemiripan $82,28 \%$ sehingga digabungkan dan diberi nama kelompok/kluster baru 1, nomor 1 (standar alkohol 60\%) dan nomor 12 (merk DT) dengan jarak 0,13 dan kemiripan 26,77\% sehingga digabungkan dan diberi nama kelompok/kluster baru 3. Dapat dilihat dari dendogram tersebut standar alkohol 60\%, 65\%, dan 70\% berada satu kelompok/kluster dengan hand sanitizer 60\%, 65\%, 70\%,75\%, dan 80\%. Standar alkohol 75\% dan $80 \%$ berada satu kelompok dengan sampel merk EL, SS, SN, dan IT. Sampel merk DT berbeda kluster dengan yang lainnya.

Untuk mendapatkan hubungan linier dari variabel multivariant dengan kadar alkohol dari standar alkohol (60\%,65\%, 70\%, 75\%, 80\%) menggunakan analisis kemometrik metode PLS (Tabel 2). Banyaknya standar minimal $2 n+n$, dimana $\mathrm{n}$ adalah komponen yang akan dianalisis. Pada penelitian ini dianalisis satu komponen 
alkohol, maka banyaknya standar yang diukur minimal $((2 \times 1)+2)=4$. Tahap selanjutnya data FTIR dilakukan analisis kemometrik metode PLS terhadap 3 rentang bilangan gelombang yaitu $4000 \mathrm{~cm}^{-1}-800 \mathrm{~cm}^{-1}$ (dipilih 14 bilangan gelombang); $2935 \mathrm{~cm}^{-1}-3013 \mathrm{~cm}^{-1} ; 3017 \mathrm{~cm}^{-1}-3060$ $\mathrm{cm}^{-1}$ (Tabel 3). Hasilnya pada rentang bilangan gelombang $2935 \mathrm{~cm}^{-1}-3013 \mathrm{~cm}^{-1}$ didapatkan nilai $\mathrm{R}^{2}$ dan akurasi alkohol dari hand sanitizer dengan nilai $\mathrm{R}^{2}=0,998$ dan akurasi 98,75 - 99,02\%; RMSEC (Root Mean Squared Error of calibration) 0,00314 dan RMSEP (Root Mean Square Error of Prediction) 0,005574; PRESS (predicted residual error sum of squqres) 0,0001361. Nilai mendekati nol sehingga pada rentang bilangan ini dapat dipakai untuk penentuan kadar alkohol dalam gel hand sanitizer.

\section{Kesimpulan}

Gabungan teknik spektroskopi FTIR dengan PCA dan CA yang telah dikembangkan untuk identifikasi dan pengelompokan kandungan alkohol dalam gel hand sanitizer mampu membedakan dan mengelompokkan kandungan alkohol dalam gel hand sanitizer. Analisis dengan PLS menunjukkan hubungan linier terbaik dengan nilai $\mathrm{R}^{2}$ 0,998 pada rentang bilangan bilangan gelombang $2935 \mathrm{~cm}^{-1}-3013 \mathrm{~cm}^{-1}$ dan akurasi 98,75 - 99,02\% untuk kadar alkohol dalam hand sanitizer. Metode yang telah dikembangkan cukup efisien dan dapat diterapkan pada sampel gel hand sanitizer.

\section{Daftar pustaka}

1. Departemen Kesehatan Republik Indonesia. Pedoman Pencegahan dan Pengendalian Infeksi di Rumah Sakit dan Fasilitas Pelayanan Kesehatan Lainnya. Jakarta: Departemen Kesehatan Republik Indonesia; 2008.

2. World Health Organization. WHO Guidelines on Hand Hygiene in Health Care. First Global Patient
Safety Challenge Clean Care is Safer Care. World Alliance for Patient Safety. World Health Organization Press; 2009.

3. CDC. Antimicrobial Spectrum and Characteristics of Hand-Hygiene Antiseptic Agents [Internet]. MMWR Morb Mortal Wkly Rep; 2002: 51(RR16):45.

4. CDC. Show Me the Science - When \& How to Use Hand Sanitizer in Community Settings. Centers for Disease Control and Prevention; 2020: 1-1.

5. Kampf G. Efficacy of ethanol against viruses in hand disinfection. Journal of Hospital Infection. 2018;98(4):331-8.

6. Mursyidi A. 2002. Alkohol dalam obat dan kosmetika. Tarjih, i, 26-36.

7. Muchtaridi M, Musfiroh I, Hambali MM, Indrayati W. Determination of Alcohol Contents of Fermentated Black Tape Ketan Based on Different Fermentation Time Using Specificgravity, Refractive Index and Gc-Ms Methods. Journal of Microbiology, Biotechnology and Food Sciences. 2012;2(3):933-46.

8. Dubowski KM. Alcohol Determination in the Clinical Laboratory. American Journal of Clinical Pathology. 1980; 74(5):747-50.

9. Hermanto D, Andayani IGAS, Honiar R, Syofiyana LM, Ismillayli N. Penentuan Kandungan Etanol dalam Makanan dan Minuman Fermentasi Tradisional Menggunakan Metode Kromatografi Gas. Chempublish Journal. 2020;5(2):105-15.

10. Albab FQ, Nukhasanah. Penetapan kadar alkohol pada kosmetik menggunakan metode kromatografi gas. Journal of Halal Science and Research. 2020;1(1):30-8.

11. Sun S, Chen J, Zhou Q Lu G, Chan K. 2010. Application of Mid-Infrared Spectroscopy in The Quality Control of Traditional Chinese Medicines. Planta Med. 2010;76:1987-96.

12. Bunaciu AA, Aboul-Enein HY, Fleschin S. 2011. Recent Applications of Fourier Transform Infrared Spectrophotometry in Herbal Medicines Analysis. Appl. Spectrosc. Rev. 2011;46:251-60.

13. Nandiyanto ABD, Oktiani R, Ragadhita R. How to read and interpret FTIR spectroscope of organic material. Indonesian Journal of Science and Tech- 
nology. 2019;4(1):97-118.

14. Gad HA, El-Ahmady SH, Abou-Shoer MI, Al-Azizi MM. Application of Chemometrics in Authentication of Herbal Medicines: A Review. Phytochem. Anal. 2012; 24: 1-24.

15. Miller JN, Miller JC. Statistics and Chemometric for Analytical Chemistry. UK: Pearson Education, Essex; 2005. Adam MJ. Chemometrics in Analytical Spectroscopy $2^{\text {nd }}$ Edition. Cambridge: The Royal Society of Chemistry; 2005.

16. Widyawati L, Mustariani BAA, Purmafitriah E. Formulasi Sediaan Gel Hand Sanitizer Ekstrak Etanol
Daun Sirsak (Annona muricata Linn.) sebagai Antibakteri terhadap Staphylococcus aureus. Jurnal Farmasetis. 2017;6(2):47-57.

17. Pavia DL, Lampman M, Kriz GZ. Introduction to Spectroscopy ( $6^{\text {th }}$ ed). Belmont: Brooks/Cole Cengage Learning; 2015.

18. Rohman A, Statistika dan Kemometrika Dasar Dalam Analisis Farmasi. Yogyakarta: Pustaka Pelajar; 2019.

19. Rohman A, Spektroskopi Inframerah dan Kemometrika untuk Analisis Farmasi, Yogyakarta: Pustaka Pelajar; 2014. 